\title{
Clinical Mortality Review in a Large COVID-19 Cohort
}

Mark P. Jarrett, MD, MBA, MS'; Susanne E. Schultz, RN, MBA²; Julie S. Lyall, RN, MSN²;

Jason J. Wang, $\mathrm{PhD}^{1}$; Lori Stier, RN, EdD²; Marcella De Geronimo, MS³; Karen L. Nelson, RN, $\mathrm{MBA}^{1}$

${ }^{1}$ Donald and Barbara Zucker School of Medicine at Hofstra/Northwell, Hempstead, New York

${ }^{2}$ Institute for Clinical Excellence and Quality/Safety, Northwell Health, New Hyde Park, New

York

${ }^{3}$ Krasnoff Quality Management Institute, Northwell Health, New Hyde Park, New York

\section{Correspondence to:}

Mark P. Jarrett, MD, MBA, MS

Professor of Medicine

Donald and Barbara Zucker School of Medicine at Hofstra/Northwell

500 Hofstra University

Hempstead, NY, 11549

516-321-6044

mjarrett@northwell.edu 
medRxiv preprint doi: https://doi.org/10.1101/2020.08.05.20168146; this version posted August 6, 2020. The copyright holder for this preprint (which was not certified by peer review) is the author/funder, who has granted medRxiv a license to display the preprint in perpetuity.

All rights reserved. No reuse allowed without permission.

\section{ABSTRACT}

Background: Northwell Health (Northwell), an integrated health system in New York, treated more than 15000 inpatients with coronavirus disease (COVID-19) at the US epicenter of the severe acute respiratory syndrome coronavirus 2 (SARS-CoV-2) pandemic. We describe the demographic characteristics of COVID-19 mortalities, observation of frequent rapid response teams (RRT)/cardiac arrest (CA) calls for non-intensive care unit (ICU) patients, and factors that contributed to RRT/CA calls.

Methods: A team of registered nurses reviewed medical records of inpatients who tested positive for SARS-CoV-2 via polymerase chain reaction (PCR) before or on admission and died between March 13 (first Northwell inpatient expiration) and April 30, 2020 at 15 Northwell hospitals. Findings for these patients were abstracted into a database and statistically analyzed. Findings: Of 2634 COVID-19 mortalities, 56.1\% had oxygen saturation levels greater than or equal to $90 \%$ on presentation and required no respiratory support. At least one RRT/CA was called on $42.2 \%$ of patients at a non-ICU level of care. Before the RRT/CA call, the most recent oxygen saturation levels for $76.6 \%$ of non-ICU patients were at least $90 \%$. At the time RRT/CA was called, $43.1 \%$ had an oxygen saturation less than $80 \%$.

Interpretation: This study represents one of the largest cohorts of reviewed mortalities that also captures data in non-structured fields. Approximately 50\% of deaths occurred at a non-ICU level of care, despite admission to the appropriate care setting with normal staffing. The data imply a sudden, unexpected deterioration in respiratory status requiring RRT/CA in a large number of non-ICU patients. Patients admitted to a non-ICU level of care suffer rapid clinical deterioration, often with a sudden decrease in oxygen saturation. These patients could benefit from additional monitoring (eg, continuous central oxygenation saturation), although this approach warrants further study. 
medRxiv preprint doi: https://doi.org/10.1101/2020.08.05.20168146; this version posted August 6, 2020. The copyright holder for this preprint (which was not certified by peer review) is the author/funder, who has granted medRxiv a license to display the preprint in perpetuity.

All rights reserved. No reuse allowed without permission.

Funding: National Institute on Aging and the National Library of Medicine of the National Institutes of Health.

\section{RESEARCH IN CONTEXT}

\section{Evidence before the study}

The world first learned of SARS-CoV-2 through a landmark study published by the Lancet in January 2020. Early evidence was limited due to the novel nature of the virus, clinician inexperience in treating COVID-19, small sample size of primarily hospital inpatients in early observational studies, use of structured datasets for data collection, and early and evolving treatment guidelines. We collected evidence from leading medical journals from January 2020 through June 2020 that primarily describe the clinical characteristics of COVID-19 (eg, patient age, sex, and comorbidities) as well as the different approaches to treatment that were being used. Our search consisted of real-time publications as they became available. Analyzing the characteristics of patients who died can help to define the clinical nature of COVID-19 and potentially suggest new care protocols.

\section{Added value of this study}

Unlike prior research, our study represents one of the largest cohorts of COVID-19 mortalities abstracted from both structured and unstructured fields in the medical record using data collected during the surge of infections in the New York metropolitan area in March through April 2020. Our study identified an unusual pattern of respiratory decompensation in patients who presented to the hospital with acceptable oxygen saturation levels and were therefore admitted to a nonICU setting for care. Through our unique analysis, we identified a cohort of patients who experienced a rapid response team/cardiac arrest call after a sudden and unexpected decrease in their oxygenation saturation levels. 
medRxiv preprint doi: https://doi.org/10.1101/2020.08.05.20168146; this version posted August 6, 2020. The copyright holder for this preprint (which was not certified by peer review) is the author/funder, who has granted medRxiv a license to display the preprint in perpetuity.

All rights reserved. No reuse allowed without permission.

\section{Implications of available evidence}

Our findings, based on over 2600 inpatient mortalities, suggest that there is a subpopulation of patients who are admitted to a non-ICU setting where continuous oxygenation saturation monitoring is not a standard, but may be warranted. Further research is needed to understand which patients are at highest risk for mortality, due to age and comorbidities, and the implications of continuous monitoring on mortality rates. This finding is relevant to a wide audience of national and international health care providers.

\section{INTRODUCTION}

Downstate New York was the first epicenter of the severe acute respiratory syndrome coronavirus 2 (SARS-CoV-2) pandemic in the United States. ${ }^{1-2}$ Northwell Health (Northwell), an integrated health system, treated more than 15000 inpatients with coronavirus disease (COVID19). Comprehensively analyzing the characteristics of those who died can help define the clinical nature of COVID-19 infection and potentially suggest new care protocols. For 7 years, Northwell has used a centralized mortality review process with data validated through rigorous internal review and inter-rater reliability (92\% to 96\%). This robust process used a customized database to review all 2634 COVID-19 mortalities in Northwell's adult acute care hospitals between March and April 2020. During this overwhelming surge, documentation was in various notes, as well as in structured fields in the electronic health record (EHR) systems. This study describes the demographic characteristics of COVID-19 mortalities and the observation of frequent calls for rapid response teams (RRT)/cardiac arrest (CA) in patients not in the intensive care unit (ICU). It also discusses factors that contributed to the RRT/CA calls, which may be a significant element in planning for a pandemic resurgence. 
medRxiv preprint doi: https://doi.org/10.1101/2020.08.05.20168146; this version posted August 6, 2020. The copyright holder for this preprint (which was not certified by peer review) is the author/funder, who has granted medRxiv a license to display the preprint in perpetuity.

All rights reserved. No reuse allowed without permission.

\section{METHODS}

Northwell is New York State's largest health care provider and private employer. With 23 hospitals (including specialty hospitals) and nearly 800 outpatient practice sites, the organization cares for over 2 million people in greater metropolitan New York. A team of registered nurses in the corporate quality department retrospectively reviewed medical records from 15 acute care hospitals. This team routinely conducts clinical reviews of all adult acute inpatient mortalitiesapproximately 5000 per year. A physician advisor was available to the team to consult on clinical questions.

Database elements were based on Northwell's experience with treating COVID-19 patients, literature review from countries that had early experience in treating patients, and clinical trials being conducted at the Feinstein Institutes for Medical Research. Also, the data were captured in the database established under the direction of critical care intensivists at the epicenter of the pandemic, other subject matter experts, and quality leadership. During data abstraction, modifications and enhancements were made to the database based on trends and emerging information. Demographics, comorbidities, clinical findings, and management of COVID-19 patients who died were analyzed.

Analyzed cases included inpatients who tested positive for SARS-CoV-2 via polymerase chain reaction (PCR) before or on admission and then died between March 13 (first Northwell inpatient death) and April 30, 2020. Emergency department (ED) mortalities were excluded. Demographic data and comorbidities were abstracted from the medical record on admitted patients. Initially data were collected on ten patient comorbidities that were deemed important and then narrowed down to six comorbidities for inclusion based on our initial analysis. Transfers from one in-system hospital to another were merged and considered as a single visit. One patient outcome measured was a call for RRT/CA. 
medRxiv preprint doi: https://doi.org/10.1101/2020.08.05.20168146; this version posted August 6, 2020. The copyright holder for this preprint (which was not certified by peer review) is the author/funder, who has granted medRxiv a license to display the preprint in perpetuity.

All rights reserved. No reuse allowed without permission.

This Institutional Review Board of Northwell Health deemed this study as exempt and waived the requirement for informed consent.

Statistical analyses were performed using chi-square for categorical variables and $t$-test for continuous variables. A multivariable logistic regression model was created to determine independent risk factors for the outcome variable. Statistical significance was considered $\mathrm{p}<0.05$. All statistical analyses were done in SAS v9.4 (SAS Institute).

\section{Role of Funding Source}

This work was supported by grants R24AG064191 from the National Institute on Aging of the National Institutes of Health and R01LM012836 from the National Library of Medicine of the National Institutes of Health. The views expressed in this paper are those of the authors and do not represent the views of the National Institutes of Health, the United States Department of Health and Human Services, or any other government entity.

\section{RESULTS}

Baseline characteristics of 2634 COVID-19 mortalities are described in table 1 . The age range was 21 to 107 years in the following categories: 21 to 39 (49;1.86\%), 40 to 59 (351; 13.3\%), 60 to 79 (1241; 47.1\%), and 80 and older (993; 37.7\%). There were 1664 (63.2\%) male and 970 (36.8\%) female patients. Of all patients, 1256 (47.7\%) were white, 463 (17.6\%) black, 230 (8.7\%) Asian, and 685 (26.0\%) other/unknown. Insurance was Medicare for the majority of patients (1839; 69.8\%). The most common comorbidities among those collected were hypertension (1719; 65.3\%), diabetes mellitus (1043; 39.6\%), and dementia (431; 16.4\%). Fewer patients had chronic obstructive pulmonary disease (COPD) (385; 14.6\%), heart failure (291; 11.1\%), and end stage renal disease (166; 6.3\%). Of these six comorbidities, more than 50\% of patients had 2 or more comorbidities and $16.9 \%$ had 0 comorbidities. The majority of patients 
medRxiv preprint doi: https://doi.org/10.1101/2020.08.05.20168146; this version posted August 6, 2020. The copyright holder for this preprint (which was not certified by peer review) is the author/funder, who has granted medRxiv a license to display the preprint in perpetuity. All rights reserved. No reuse allowed without permission.

with a known body mass index (BMI) of 25 or more were categorized as follows: 25 to 29.99 (732; 27.8\%), 30 to 34.99 (401; 15.2\%), 35 to 39.99 (190; 7.2\%), and 40 or higher (147; 5.6\%). Most patients were admitted from home (1895; 71.9\%). Of the remaining patients, 411 (15.6\%) were admitted from a skilled nursing facility (SNF), 201 (7.6\%) from an acute care facility, and 127 (4.8\%) from rehabilitation. The number of patients with a prior ED visit within 7 days of admission was 125 (4.8\%), and within 48 hours of admission was 51 (1.9\%). The number of patients readmitted within 30 days was 194 (7.4\%), within 7 days was 75 (2.9\%), and within 24 hours was 20 (0.8\%). On presentation, most (1478; 56.1\%) patients had an oxygen saturation level greater than or equal to 90\%, and 1397 (53.0\%) required no respiratory support. Others required nasal cannula (363; 13.8\%), non-rebreather (742; 28.2\%), and mechanical ventilation (24; 0.9\%). More than half of the patients who died (1403; 53.2\%) required mechanical ventilation during their clinical course. Of those patients, 1332 (94.9\%) had increasing oxygen requirements before intubation, 1259 (89.7\%) were on traditional ventilators, 142 (10.1\%) were on converted BiPAP machines, and $2(0.1 \%)$ were on anesthesia machines. The length of time on mechanical ventilation was from 0 to 7 days for 851 (60.7\%) patients and was 8 days or more for 552 (39.3\%) patients.

Prone positioning was documented for 756 patients (28.7\%), and 270 (10.3\%) patients were terminally weaned. Do Not Resuscitate (DNR) orders were complete for 1631 (50.2\%) patients. A palliative care consult was provided to 1014 (38.5\%) patients. At the time of death, the level of care was the ICU for 1299 (49.3\%) patients and non-ICU for 1335 (50.7\%) patients.

A total of 1112 (42.2\%) patients had a RRT/CA call at a non-ICU level of care versus 1522 (57.8\%) who did not. As shown in table 2 and table 3, the RRT/CA group was significantly different from the non-RRT/CA group in terms of age, race, and comorbidities. There were 618 patients (55.6\%) between 60 and 79 years old in the RRT/CA group compared to 623 patients (40.9\%) in the non-RRT/CA group. In terms of race, white was significantly lower in the 
medRxiv preprint doi: https://doi.org/10.1101/2020.08.05.20168146; this version posted August 6, 2020. The copyright holder for this preprint (which was not certified by peer review) is the author/funder, who has granted medRxiv a license to display the preprint in perpetuity.

All rights reserved. No reuse allowed without permission.

RRT/CA group (36.3\% versus 55.9\%; $\mathrm{p}<0.0001$ ). The RRT/CA cohort had a significantly higher rate of diabetes mellitus (44.2\% versus 36.3\%, $\mathrm{p}<0.0001$ ). Patients in the RRT/CA cohort were more likely to be admitted from home (926; 83.3\%) versus the non-RRT/CA cohort (969;

63.7\%). The RRT/CA cohort versus the non-RRT/CA cohort was more likely to be admitted to a medical/surgical unit [(576; 51.8\%) versus (654; 42.9\%)] or telemetry/step-down unit [(455;

$40.9 \%$ ) versus (408; 26.8\%)], and to die at an ICU level of care [(671; 60.3\%) versus (628;

41.3\%)]. An overall length of stay (LOS) of 8 days or more was higher for the RRT/CA cohort

(645; 58.0\%) than the non-RRT/CA cohort (569; 37.4\%), as was an ICU LOS of 0 to 7 days

[(472; 42.0\%) versus $(400 ; 26.3 \%)]$ and 8 days or more $[(271 ; 24.4 \%)$ versus $(303 ; 19.9 \%)]$.

After adjusting for demographic and clinical characteristics, oxygen saturation levels at presentation were significant for the RRT/CA cohort at oxygen saturation levels of $80 \%$ to $89 \%$ [odds ratio $(\mathrm{OR})=1.988$; 95\% CI: $1.511,2.616$ ] and of $90 \%$ or higher $(\mathrm{OR}=2.517 ; 95 \% \mathrm{CI}$ : 1.962, 3.230). See logistic regression results (table 4).

\section{DISCUSSION}

This study represents a review of one of the largest cohorts of COVID-19 mortality that includes data documented in non-structured fields within the EHR. The experienced team of registered nurses was able to extract detailed information from the medical record that is typically not included in a structured dataset analysis. The demographics of the patients who died is similar to other published studies: age predominately over 69, male majority, payor mix [reflecting age and Medicare, along with a low number of self-pay $(41 ; 1.6 \%)]$, and multiple comorbidities. ${ }^{3-12}$ This study provides a detailed clinical picture of the circumstances that precede the sudden deterioration in non-ICU patients reported by clinicians, but not fully examined in the literature. A striking feature of COVID-19 that has been reported is the rapid progression of of respiratory failure soon after the the onset of dyspnea and hypoxemia. ${ }^{13}$ The National Institutes for Health 
medRxiv preprint doi: https://doi.org/10.1101/2020.08.05.20168146; this version posted August 6, 2020. The copyright holder for this preprint (which was not certified by peer review) is the author/funder, who has granted medRxiv a license to display the preprint in perpetuity.

All rights reserved. No reuse allowed without permission.

(NIH) has reported that hypoxemia is common in hospitalized patients with COVID-19 and that the criteria for hospital admission, intensive care unit (ICU) admission, and mechanical ventilation differ between countries. ${ }^{14}$ In some hospitals in the United States, $>25 \%$ of hospitalized patients require ICU care, mostly due to acute respiratory failure.

Recommendations from the NIH are close monitoring for worsening respiratory status for adults with COVID-19 who are receiving supplemental oxygen. These recommendations are aligned with our findings in the non-ICU patient population.

Approximately $50 \%$ of deaths occurred at a non-ICU level of care, despite admission to the appropriate care setting with normal staffing. Our analysis of 1112 patients who experienced at least one RRT/CA at a non-ICU level of care revealed that $64.4 \%$ required an escalation in level of care. Of the 1112 RRT/CA patients, 664 (59.7\%) presented to the hospital with oxygen saturation levels greater than or equal to 90\%. In addition, 687 patients (61.8\%) had no oxygen support. Of the RTT/CA patients 1031 (92.7\%) were admitted to a non-ICU level of care with normal staffing levels which was appropriate based on their care needs. At presentation to the ED, the oxygen saturation levels for these patients were significantly higher than those for patients admitted to the ICU. Before the RRT/CA, the most recent oxygen saturation levels recorded for the non-ICU patients remained high at greater than or equal to $90 \%$ for 852 patients (76.7\%). Oxygen saturations were documented within two hours of the RRT/CA in 454 (40.9\%) patients in the RRT/CA cohort. When the RRT/CA was called, 479 patients (43.1\%) had an oxygen saturation less than $80 \%$, and 868 patients (78.1\%) were on a non-rebreather/nonrebreather with nasal cannula. These data imply a sudden, unexpected deterioration in respiratory status requiring an RRT/CA call in a large number of non-ICU patients. 
medRxiv preprint doi: https://doi.org/10.1101/2020.08.05.20168146; this version posted August 6, 2020. The copyright holder for this preprint (which was not certified by peer review) is the author/funder, who has granted medRxiv a license to display the preprint in perpetuity.

All rights reserved. No reuse allowed without permission.

\section{LIMITATIONS}

This study includes the following limitations. First, the study focuses on the demographic and clinical characteristics of in-hospital COVID-19 patients who died between March 13, 2020 and April 30, 2020; it does not provide a comparison group of similar patients who survived during the same time period. Second, data were obtained from the EHR and manually abstracted from medical records through retrospective review, but some routine documentation was less detailed due to the volume of patients being treated. Third, race was documented as other/unknown in 685 patients (26\%); therefore, conclusions about race could not be drawn. Fourth, missing BMI data were included in the category of "Unknown" BMI. Finally, the study does not recognize a specific trigger that can distinguish which non-ICU patients in the cohort should be monitored.

\section{CONCLUSION}

Patients admitted to a non-ICU level of care appear to suffer a rapid clinical deterioration, often with the hallmark of a sudden decrease in oxygen saturation. This finding suggests non-ICU patients could benefit from additional monitoring, such as continuous central oxygenation saturation. The availability of wireless patch monitoring should be considered, along with other methods, such as carbon dioxide and/or cardiac monitoring. Although this approach does not ensure reduced mortality, the number of RRT/CA calls infers this area warrants further study.

\section{CONTRIBUTORS}

MPJ had full access to all data in the study and takes responsibility for the integrity of the data and the accuracy of the data analysis. MPJ, SES, JSL, and KLN were responsible for the concept and design of the study. MPJ, SES, JSL, JJW, LS, MDG, and KLN were responsible for data acquisition, analysis, and interpretation. MPJ, SES, JSL, JJW, LS, and KLN were responsible for 
medRxiv preprint doi: https://doi.org/10.1101/2020.08.05.20168146; this version posted August 6, 2020. The copyright holder for this preprint (which was not certified by peer review) is the author/funder, who has granted medRxiv a license to display the preprint in perpetuity.

All rights reserved. No reuse allowed without permission.

drafting the manuscript. MPJ, SES, JSL, JJW, LS, MDG, and KLN were responsible for critical revision of the manuscript for important intellectual content. JJW was responsible for the statistical analysis. MPJ, SES, JSL, JJW, LS, MDG, and KLN were responsible for administrative, technical, and material support. MPJ supervised the study.

\section{ACKNOWLEDGMENTS}

We thank the Northwell Health Institute for Clinical Excellence \& Quality/Safety: Mary Cama, RN, MSN; Patricia Meo, RN, BSN; Amy Logeman, RN, BSN, CPPS; Maureen McCarthy, RN, BSN; Josephine Fernandez-Kapilevich, RN, BSN; Theresa A. Droluk, RN, BSN; Jessica Martin, RN, BSN, RN-BC; Allison Carballo, RN, MBA; Jimmy Diaz, BS. We also thank the Northwell Health, Krasnoff Quality Management Institute: Alex Ma; Kahliik S. Burrell; Mark P. Tursi, MBA. We would like to acknowledge the contributions of the Northwell Health COVID-19 Research Consortium, including Crystal R. Herron, PhD, and Jennifer C. Johnson, MS, for editorial support. We acknowledge and honor all of our Northwell team members who consistently put themselves in harm's way during the COVID-19 pandemic. We dedicate this article to them, as their vital contribution to knowledge about COVID-19 and sacrifices on the behalf of patients made it possible.

This work was supported by grants R24AG064191 from the National Institute on Aging of the National Institutes of Health and R01LM012836 from the National Library of Medicine of the National Institutes of Health.

\section{DATA SHARING}

The data that support the findings of this study are available on request from

COVID19@northwell.edu. The data are not publicly available due to restrictions as it could compromise the privacy of research participants. 
medRxiv preprint doi: https://doi.org/10.1101/2020.08.05.20168146; this version posted August 6, 2020. The copyright holder for this preprint (which was not certified by peer review) is the author/funder, who has granted medRxiv a license to display the preprint in perpetuity.

All rights reserved. No reuse allowed without permission.

\section{DECLARATION OF INTERESTS}

We declare no competing interests. 


\section{REFERENCES}

1. The Center for Systems Science and Engineering at Johns Hopkins University. COVID19 dashboard. 2020. https://

gisanddata.maps.arcgis.com/apps/opsdashboard/ index.html\#/

bda7594740fd40299423467b48e9ecf6. (accessed March 24, 2020).

2. New York State Department of Health. COVID-19 Tracker. 2020.

https://covid19tracker.health.ny.gov/views/NYS-COVID19 Tracker/NYSDOHCOVID19Tracker-Map?\%. (accessed May 7, 2020).

3. CDC COVID-19 Response Team. Preliminary estimates of the prevalence of selected underlying health conditions among patients with coronavirus disease 2019 - United States, February 12-March 28, 2020. MMWR Morb Mortal Wkly Rep 2020; 69: 382-386. doi:10.15585/mmwr.mm6913e2

4. Wortham JM, Lee JT, Althomsons S, et al. Characteristics of Persons Who Died with COVID-19 —United States, February 12-May 18, 2020. MMWR Morb Mortal Wkly Rep ePub: 10 July 2020. doi:10.15585/mmwr.mm6928e1

5. Wang C, Horby PW, Hayden FG, Gao GF. A novel coronavirus outbreak of global health concern. Lancet 2020; 395: 470-473. doi:10.1016/ S0140-6736(20)30185-9

6. Richardson S, Hirsch JS, Narasimhan M, et al; and the Northwell COVID-19 Research Consortium. Presenting characteristics, comorbidities, and outcomes among 5700 patients hospitalized with COVID-19 in the New York City area. JAMA Published online April 22, 2020. Corrected on April 24, 2020. doi:10.1001/jama.2020.6775

7. Zhou F, Yu T, Du R, et al. Clinical course and risk factors for mortality of adult inpatients with COVID-19 in Wuhan, China: a retrospective cohort study. Lancet 2020;

395: 1054-1062. doi:10.1016/S0140-6736(20)30566-3 
8. Goyal P, Choi JJ, Pinheiro LC, et al. Clinical characteristics of Covid-19 in New York City. N Engl J Med Published online April 17, 2020. doi:10.1056/ NEJMc2010419

9. Petrilli CM, Jones SA, Yang J, et al. Factors associated with hospitalization and critical illness among 4,103 patients with COVID-19 disease in New York City. medRxiv Preprint posted April 11, 2020. doi:10.1101/2020.04.08.20057794

10. Garg S, Kim L, Whitaker M, et al. Hospitalization rates and characteristics of patients hospitalized with laboratory-confirmed coronavirus disease 2019 - COVID-NET, 14 States, March 1-30, 2020. MMWR Morb Mortal Wkly Rep 2020; 69: 458-464. doi:10.15585/mmwr.mm6915e3

11. Stokes EK, Zambrano LD, Anderson KN, et al. Coronavirus Disease 2019 Case Surveillance — United States, January 22-May 30, 2020. MMWR Morb Mortal Wkly Rep ePub: 15 June 2020. doi:10.15585/mmwr.mm6924e2

12. Yancy, CW. COVID-19 and African Americans. JAMA Published online April 15, 2020. doi:10.1001/jama.2020.6548

13. Berlin, DA, Gulick, RM, Martinez, FJ.. Severe Covid-19. N Engl J Med Published online May 15, 2020. doi: 10.1056/NEJMcp2009575

14. NIH. COVID-19 treatment guidelines. https://covid19treatmentguidelines. nih.gov/introduction/. (accessed April 24, 2020). 
Table 1. Baseline characteristics of Patients Hospitalized with COVID-19 Mortality (n=2634)

\begin{tabular}{|c|c|}
\hline Baseline characteristics & No. (\%) \\
\hline \multicolumn{2}{|l|}{ Age } \\
\hline $21-39$ & $49(1.86)$ \\
\hline $40-59$ & $351(13.3)$ \\
\hline $60-79$ & $1241(47.1)$ \\
\hline $80 \leq$ & $993(37.7)$ \\
\hline \multicolumn{2}{|l|}{ Sex } \\
\hline Male & $1664(63.2)$ \\
\hline Female & $970(36.8)$ \\
\hline \multicolumn{2}{|l|}{ Race } \\
\hline White & $1256(47.7)$ \\
\hline Black & $463(17.6)$ \\
\hline Asian & $230(8.7)$ \\
\hline Other/Unknown & $685(26.0)$ \\
\hline \multicolumn{2}{|l|}{ Payment method } \\
\hline Commercial & $413(15.7)$ \\
\hline Medicaid & $341(13.0)$ \\
\hline Medicare & $1839(69.8)$ \\
\hline Self-pay & $41(1.6)$ \\
\hline \multicolumn{2}{|l|}{ Comorbidities } \\
\hline Hypertension & $1719(65.3)$ \\
\hline COPD & $385(14.6)$ \\
\hline Diabetes Mellitus & $1043(39.6)$ \\
\hline Heart Failure & $291(11.1)$ \\
\hline Dementia & $431(16.4)$ \\
\hline End Stage Renal Disease & $166(6.3)$ \\
\hline 0 Comorbidities & 445 (16.9) \\
\hline 1 Comorbidity & 839 (31.9) \\
\hline 2 Comorbidities & $934(35.5)$ \\
\hline 3 Comorbidities & $343(13.0)$ \\
\hline 4 Comorbidities & $66(2.5)$ \\
\hline 5 Comorbidities & $7(0.3)$ \\
\hline 6 Comorbidities & $0(0.0)$ \\
\hline \multicolumn{2}{|l|}{ BMI } \\
\hline Unknown & 494 (18.8) \\
\hline$<18.5$ & $82(3.1)$ \\
\hline $18.5-24.99$ & $588(22.3)$ \\
\hline $25-29.99$ & $732(27.8)$ \\
\hline $30-34.99$ & $401(15.2)$ \\
\hline $35-39.99$ & $190(7.2)$ \\
\hline $40 \leq$ & $147(5.6)$ \\
\hline \multicolumn{2}{|l|}{ Admit source } \\
\hline Home & $1895(72.0)$ \\
\hline Rehabilitation & $127(4.8)$ \\
\hline Skilled Nursing Facility & $411(15.6)$ \\
\hline Transfer from another acute care hospital & $201(7.6)$ \\
\hline
\end{tabular}


medRxiv preprint doi: https://doi.org/10.1101/2020.08.05.20168146; this version posted August 6, 2020. The copyright holder for this preprint (which was not certified by peer review) is the author/funder, who has granted medRxiv a license to display the preprint in perpetuity. All rights reserved. No reuse allowed without permission.

\begin{tabular}{|c|c|c|}
\hline \multicolumn{3}{|l|}{ Emergency department visit } \\
\hline Within 48 hours of this admission & \multicolumn{2}{|l|}{$51(1.9)$} \\
\hline Within 7 days of this admission & \multicolumn{2}{|l|}{$125(4.8)$} \\
\hline \multicolumn{3}{|l|}{ Readmission } \\
\hline Within 24 Hours & \multicolumn{2}{|l|}{$20(0.8)$} \\
\hline Within 7 Days & \multicolumn{2}{|l|}{$75(2.9)$} \\
\hline Within 30 Days & \multicolumn{2}{|l|}{$194(7.4)$} \\
\hline \multicolumn{3}{|l|}{ Level of care at time of death } \\
\hline ICU & \multicolumn{2}{|l|}{$1299(49.3)$} \\
\hline Non-ICU & \multicolumn{2}{|l|}{$1335(50.7)$} \\
\hline \multicolumn{3}{|l|}{ Level of care at time of admission } \\
\hline ICU & \multicolumn{2}{|l|}{$541(20.5)$} \\
\hline Medical/Surgical & \multicolumn{2}{|l|}{$1230(46.7)$} \\
\hline Telemetry/Stepdown & \multicolumn{2}{|l|}{$863(32.8)$} \\
\hline \multicolumn{3}{|l|}{ Overall length of stay } \\
\hline $0-7$ & \multicolumn{2}{|l|}{$1420(53.9)$} \\
\hline $8 \leq$ & \multicolumn{2}{|l|}{$1214(46.1)$} \\
\hline \multicolumn{3}{|l|}{ ICU length of stay, $d$} \\
\hline $0-7$ & \multicolumn{2}{|l|}{$872(33.1)$} \\
\hline $8 \leq$ & \multicolumn{2}{|l|}{$574(21.8)$} \\
\hline \multicolumn{3}{|l|}{ Oxygen saturation on presentation } \\
\hline$<80$ & \multicolumn{2}{|l|}{$459(17.4)$} \\
\hline $80-89.9$ & \multicolumn{2}{|l|}{$667(25.3)$} \\
\hline $90 \geq$ & $1478(56.1)$ & \\
\hline UTD & $30(1.2)$ & \\
\hline Initial respiratory support on presentation & & \\
\hline None & $1397(53.0)$ & \\
\hline Nasal cannula & $363(13.8)$ & \\
\hline Non-rebreather & $742(28.2)$ & \\
\hline Ventilator & $24(0.9)$ & \\
\hline High-flow nasal cannula & $8(0.3)$ & \\
\hline Ventimask & $11(0.4)$ & \\
\hline BiPAP & $13(0.5)$ & \\
\hline Other & $27(1.0)$ & \\
\hline UTD & $49(1.9)$ & \\
\hline RRT/CA while not at ICU level of care & & \\
\hline Yes & $1112(42.2)$ & \\
\hline Mechanical Ventilation & $\mathrm{n}=2634$ & $\mathrm{n}=1403$ subset \\
\hline Yes & $1403(53.2)$ & $1403(100.0)$ \\
\hline Subset $(\mathrm{n}=1403)$ & & \\
\hline Traditional ventilator & 1259 (47.9) & 1259 (89.7) \\
\hline Converted BiPAP & $142(0.1)$ & $142(10.1)$ \\
\hline Anesthesia machine & $2(0.08)$ & $2(0.1)$ \\
\hline Increased oxygen requirement prior to $\mathrm{MV}$ & $1332(50.6)$ & $1332(94.9)$ \\
\hline Mechanical ventilation length, $d(n=1403)$ & & \\
\hline $0-7$ & $851(32.3)$ & $851(60.7)$ \\
\hline $8 \geq$ & $552(20.9)$ & $552(39.3)$ \\
\hline Terminal wean $(n=1403)$ & & \\
\hline Yes & $270(10.3)$ & $270(10.3)$ \\
\hline
\end{tabular}


medRxiv preprint doi: https://doi.org/10.1101/2020.08.05.20168146; this version posted August 6, 2020. The copyright holder for this preprint (which was not certified by peer review) is the author/funder, who has granted medRxiv a license to display the preprint in perpetuity. All rights reserved. No reuse allowed without permission.

\begin{tabular}{|l|l|}
\hline Proning & \\
\hline Yes & $756(28.7)$ \\
\hline No & $1878(71.3)$ \\
\hline Proning without MV $(\mathrm{n}=756)$ & $191(25.3)$ \\
\hline Proning prior to MV (n=756) & $213(28.2)$ \\
\hline Proning during MV (n=756) & $214(28.3)$ \\
\hline $\begin{array}{l}\text { Proning prior to and during MV } \\
\text { (n=756) }\end{array}$ & $138(18.3)$ \\
\hline DNR complete & \\
\hline Yes & $1631(61.9)$ \\
\hline Palliative care consult & $1014(38.5)$ \\
\hline Yes & \\
\hline Clinical trial inclusion & $114(4.3)$ \\
\hline Yes & \\
\hline
\end{tabular}

Abbreviations: BiPAP, bilevel positive airway pressure; BMI, body mass index; COPD, chronic obstructive pulmonary disease; DNR, do not resuscitate; ICU, intensive care unit; MV, mechanical ventilation; UTD, unable to determine

Table 2. Baseline Characteristics of COVID-19 Mortalities that Experienced a RRT/CA at a NonICU Level of Care

\begin{tabular}{|l|l|l|l|}
\hline \multicolumn{2}{|l|}{ RRT/CA (n=2634) } \\
\hline Baseline characteristics & $\begin{array}{l}\text { Yes, No. (\%) } \\
(\mathbf{n}=1112)\end{array}$ & $\begin{array}{l}\text { No, No. (\%) } \\
\text { (n=1522) }\end{array}$ & p value \\
\hline Age & & & $<0.0001$ \\
\hline $21-39$ & $19(1.7)$ & $30(2.0)$ & \\
\hline $40-59$ & $194(17.5)$ & $157(10.3)$ & \\
\hline $60-79$ & $618(55.6)$ & $623(40.9)$ & \\
\hline $80 \leq$ & $281(25.3)$ & $712(40.8)$ & \\
\hline Sex & & & 0.3466 \\
\hline Male & $714(64.2)$ & $950(62.4)$ & \\
\hline Female & $398(35.8)$ & $572(37.6)$ & \\
\hline Race & & & $<0.0001$ \\
\hline White & $404(36.3)$ & $852(55.9)$ & \\
\hline Black & $235(21.1)$ & $228(15.0)$ & \\
\hline Asian & $125(11.2)$ & $105(6.9)$ & \\
\hline Other/Unknown & $348(31.3)$ & $337(22.1)$ & \\
\hline Payment method & & & $<0.0001$ \\
\hline Commercial & $226(20.3)$ & $187(12.3)$ & \\
\hline Medicaid & $166(14.9)$ & $175(11.5)$ & \\
\hline Medicare & $702(63.1)$ & $1137(74.7)$ & \\
\hline Self-pay & $18(1.6)$ & $23(1.5)$ & \\
\hline Comorbidities & & & \\
\hline Hypertension & & & 0.2365 \\
\hline Yes & $740(66.5)$ & $979(64.3)$ & \\
\hline No & $372(33.5)$ & $543(35.7)$ & \\
\hline COPD & & & \\
\hline Yes & $147(13.2)$ & $238(15.6)$ & \\
\hline No & $965(86.8)$ & $1284(84.4)$ & \\
\hline & & & \\
\hline
\end{tabular}


medRxiv preprint doi: https://doi.org/10.1101/2020.08.05.20168146; this version posted August 6, 2020. The copyright holder for this preprint (which was not certified by peer review) is the author/funder, who has granted medRxiv a license to display the preprint in perpetuity. All rights reserved. No reuse allowed without permission.

\begin{tabular}{|c|c|c|c|}
\hline Diabetes mellitus & & & $<0.0001$ \\
\hline Yes & $491(44.2)$ & $552(36.3)$ & \\
\hline No & 621 (55.9) & $970(63.7)$ & \\
\hline Heart failure & & & 0.0339 \\
\hline Yes & $106(9.5)$ & $185(12.2)$ & \\
\hline No & $1006(90.5)$ & $1337(87.8)$ & \\
\hline Dementia & & & $<0.0001$ \\
\hline Yes & $98(8.8)$ & 333 (21.9) & \\
\hline No & $1014(91.2)$ & 1189 (78.1) & \\
\hline End stage renal disease & & & 0.0154 \\
\hline Yes & $85(7.6)$ & $81(5.3)$ & \\
\hline No & 1027 (92.4) & 1441 (94.7) & \\
\hline 0 Comorbidities & $202(18.2)$ & $243(15.9)$ & 0.4721 \\
\hline 1 Comorbidity & 355 (31.9) & $484(31.8)$ & \\
\hline 2 Comorbidities & 388 (34.9) & 546 (35.9) & \\
\hline 3 Comorbidities & $134(12.1)$ & $209(13.7)$ & \\
\hline 4 Comorbidities & $31(2.8)$ & $35(2.3)$ & \\
\hline 5 Comorbidities & $2(0.2)$ & $5(0.3)$ & \\
\hline BMI & & & $<0.0001$ \\
\hline Unknown & $136(12.2)$ & 358 (23.5) & \\
\hline$<18.5$ & $22(1.9)$ & $60(3.9)$ & \\
\hline $18.5-24.99$ & $236(21.2)$ & $352(23.1)$ & \\
\hline $25-29.99$ & $352(31.7)$ & $380(24.9)$ & \\
\hline $30-34.99$ & 206 (18.5) & $195(12.8)$ & \\
\hline $35-39.99$ & $88(7.9)$ & $102(6.7)$ & \\
\hline $40 \leq$ & $72(6.5)$ & $75(4.9)$ & \\
\hline Admit source & & & $<0.0001$ \\
\hline Home & 926 (83.3) & 969 (63.7) & \\
\hline Rehabilitation & $34(3.0)$ & $93(6.1)$ & \\
\hline Skilled nursing facility & $80(7.2)$ & $331(21.7)$ & \\
\hline $\begin{array}{l}\text { Transfer from another acute care } \\
\text { Hospital }\end{array}$ & $72(6.5)$ & $129(8.5)$ & \\
\hline \multicolumn{4}{|l|}{ Emergency department visit } \\
\hline Within 48 hours of this admission & & & 0.0325 \\
\hline Yes & $29(2.6)$ & $22(1.5)$ & \\
\hline No & $1083(97.4)$ & $1500(98.6)$ & \\
\hline Within 7 days of this admission & & & 0.1268 \\
\hline Yes & $61(5.5)$ & $64(4.2)$ & \\
\hline No & 1051 (94.5) & $1458(95.8)$ & \\
\hline \multicolumn{4}{|l|}{ Readmission } \\
\hline Within 24 hours & & & 0.5118 \\
\hline Yes & $7(0.6)$ & $13(0.9)$ & \\
\hline No & $1105(99.4)$ & $1509(99.2)$ & \\
\hline Within 7 days & & & 0.8751 \\
\hline Yes & $31(2.8)$ & $44(2.9)$ & \\
\hline No & $1081(97.2)$ & $1478(97.1)$ & \\
\hline Within 30 days & & & 0.0997 \\
\hline Yes & $71(6.4)$ & $123(8.1)$ & \\
\hline
\end{tabular}


medRxiv preprint doi: https://doi.org/10.1101/2020.08.05.20168146; this version posted August 6, 2020. The copyright holder for this preprint (which was not certified by peer review) is the author/funder, who has granted medRxiv a license to display the preprint in perpetuity. All rights reserved. No reuse allowed without permission.

\begin{tabular}{|c|c|c|c|}
\hline No & 1041 (93.6) & 1399 (91.9) & \\
\hline \multicolumn{4}{|l|}{ Level of care at time of death } \\
\hline ICU & $671(60.3)$ & $628(41.3)$ & \\
\hline Non-ICU & $441(39.7)$ & $894(58.7)$ & \\
\hline Level of care at time of admission & & & $<0.0001$ \\
\hline ICU & $81(7.3)$ & $460(30.2)$ & \\
\hline Medical/Surgical & $576(51.8)$ & 654 (42.9) & \\
\hline Telemetry/Stepdown & 455 (40.9) & $408(26.8)$ & \\
\hline Overall length of stay, $d$ & & & $<0.0001$ \\
\hline $0-7$ & $467(42.0)$ & $953(62.6)$ & \\
\hline $8 \leq$ & $645(58.0)$ & $569(37.4)$ & \\
\hline ICU length of stay, $d$ & & & $<0.0001$ \\
\hline $0-7$ & $472(42.5)$ & $400(26.3)$ & \\
\hline $8 \leq$ & $271(24.4)$ & 303 (19.9) & \\
\hline Oxygen saturation on presentation & & & $<0.0001$ \\
\hline$<80$ & $152(13.7)$ & $307(20.2)$ & \\
\hline $80-89.9$ & $289(26.0)$ & $378(24.8)$ & \\
\hline $90 \leq$ & 664 (59.7) & $814(53.5)$ & \\
\hline UTD & $7(0.6)$ & $23(1.5)$ & \\
\hline $\begin{array}{l}\text { Initial respiratory support on } \\
\text { presentation }\end{array}$ & & & $<0.0001$ \\
\hline None & $687(61.8)$ & $710(46.7)$ & \\
\hline Nasal cannula & $161(14.5)$ & $202(13.3)$ & \\
\hline High-flow nasal cannula & $0(0.0)$ & $8(0.5)$ & \\
\hline Ventimask & $2(0.2)$ & $9(0.6)$ & \\
\hline BiPAP & $2(0.2)$ & $11(0.7)$ & \\
\hline Non-rebreather & $239(21.5)$ & $503(33.1)$ & \\
\hline Ventilator & $1(0.1)$ & $23(1.5)$ & \\
\hline Other & $4(0.4)$ & $23(1.5)$ & \\
\hline UTD & $16(1.4)$ & $33(2.2)$ & \\
\hline \multicolumn{4}{|l|}{ Mechanical ventilation } \\
\hline Yes & $723(65.0)$ & $680(44.7)$ & $<0.0001$ \\
\hline Traditional ventilator & $650(58.5)$ & $609(40.0)$ & \\
\hline Converted BiPAP & $71(6.4)$ & $71(4.7)$ & \\
\hline Anesthesia machine & $2(0.2)$ & $0(0.0)$ & \\
\hline Increased oxygen requirement before MV & $699(62.9)$ & $633(41.6)$ & $<0.0001$ \\
\hline \multicolumn{4}{|l|}{ Mechanical ventilation length, $d$} \\
\hline $0-7$ & $461(41.5)$ & $390(25.6)$ & \\
\hline $8 \leq$ & $262(23.6)$ & $290(19.1)$ & \\
\hline Terminal wean & & & 0.5166 \\
\hline Yes & $109(9.8)$ & $161(10.6)$ & \\
\hline No & $1003(90.2)$ & $1361(89.4)$ & \\
\hline Proning & & & $<0.0001$ \\
\hline Yes & $500(45.0)$ & $256(16.8)$ & \\
\hline No & $612(54.9)$ & $1266(83.2)$ & \\
\hline Proning without MV & $116(10.4)$ & $75(4.9)$ & \\
\hline Proning before MV & $171(15.4)$ & $42(2.7)$ & \\
\hline Proning during MV & $99(8.9)$ & $115(7.5)$ & \\
\hline Proning before and during MV & $114(10.3)$ & $24(1.6)$ & \\
\hline
\end{tabular}


medRxiv preprint doi: https://doi.org/10.1101/2020.08.05.20168146; this version posted August 6, 2020. The copyright holder for this preprint (which was not certified by peer review) is the author/funder, who has granted medRxiv a license to display the preprint in perpetuity. All rights reserved. No reuse allowed without permission.

\begin{tabular}{|l|l|l|l|}
\hline DNR complete & & & $<0.0001$ \\
\hline Yes & $558(50.2)$ & $1073(70.5)$ & \\
\hline No & $554(49.8)$ & $449(29.5)$ & \\
\hline Palliative care consult & & & 0.0005 \\
\hline Yes & $385(34.6)$ & $629(41.3)$ & \\
\hline No & $727(65.4)$ & $893(58.7)$ & \\
\hline Clinical trial inclusion & & & \\
\hline Yes & $91(8.2)$ & $23(1.5)$ & \\
\hline No & $1021(91.8)$ & $1499(98.5)$ & \\
\hline
\end{tabular}

Abbreviations: BiPAP, bilevel positive airway pressure; BMI, body mass index; COPD, chronic obstructive pulmonary disease; DNR, do not resuscitate; ICU, intensive care unit; MV, mechanical ventilation; RRT/CA, Rapid Response Team/Cardiac Arrest; UTD, unable to determine.

Table 3. Additional characteristics associated with RRT/CA While on a Non-ICU Level of Care (n=1112)

\begin{tabular}{|l|l|}
\hline & No. (\%) \\
\hline $\begin{array}{l}\text { Required escalation in level of care } \\
\text { following initial RRT/CA }\end{array}$ & \\
\hline Yes & $716(64.4)$ \\
\hline $\begin{array}{l}\text { Oxygen saturation at time RRT/CA } \\
\text { initiated }\end{array}$ & \\
\hline$<80$ & $479(43.1)$ \\
\hline $80-89$ & $407(36.6)$ \\
\hline $90 \leq$ & $128(11.5)$ \\
\hline UTD & $98(8.8)$ \\
\hline $\begin{array}{l}\text { Oxygen supplement at time RRT/CA } \\
\text { initiated }\end{array}$ & \\
\hline $\begin{array}{l}\text { Non-rebreather with or without nasal } \\
\text { Cannula }\end{array}$ & $868(78.1)$ \\
\hline Nasal cannula & $147(13.2)$ \\
\hline Room air & $40(3.6)$ \\
\hline Venti mask & $18(1.6)$ \\
\hline Ventilator & $11(1.0)$ \\
\hline High-flow nasal cannula & $9(0.8)$ \\
\hline BiPAP & $5(0.4)$ \\
\hline UTD & $14(1.3)$ \\
\hline $\begin{array}{l}\text { Most recent oxygen saturation before } \\
\text { RRT/CA initiated }\end{array}$ & \\
\hline$<80$ & $43(3.9)$ \\
\hline $80-89$ & $211(18.9)$ \\
\hline $90 \leq$ & $852(76.7)$ \\
\hline UTD & $6(0.5)$ \\
\hline $\begin{array}{l}\text { Documented timing of most recent oxygen } \\
\text { saturation before RRT/CA initiated, h }\end{array}$ \\
\hline$<1$ & $263(23.7)$ \\
\hline $1-2$ & $191(17.2)$ \\
\hline $2-3$ & $140(12.6)$ \\
\hline & \\
\hline & \\
\hline
\end{tabular}


medRxiv preprint doi: https://doi.org/10.1101/2020.08.05.20168146; this version posted August 6, 2020. The copyright holder for this preprint (which was not certified by peer review) is the author/funder, who has granted medRxiv a license to display the preprint in perpetuity. All rights reserved. No reuse allowed without permission.

\begin{tabular}{|l|l|}
\hline $3-4$ & $109(9.8)$ \\
\hline $4<$ & $409(36.8)$ \\
\hline
\end{tabular}

Abbreviations: BiPAP, bilevel positive airway pressure; RRT/CA, Rapid Response Team/Cardiac Arrest; UTD, unable to determine.

Table 4. Regression Analysis of COVID-19 Mortalities that Experienced a RRT/CA at a Non-ICU Level of Care $(n=2634)$

\begin{tabular}{|c|c|c|c|c|c|}
\hline $\begin{array}{l}\text { Baseline } \\
\text { characteristics }\end{array}$ & Estimate & $p$ value & Odds ratio & \multicolumn{2}{|c|}{ 95\% CI Estimate } \\
\hline \multicolumn{6}{|l|}{ Age } \\
\hline $50-69$ & 0.2653 & 0.1961 & 1.304 & 0.872 & 1.949 \\
\hline $70-79$ & 0.1721 & 0.4420 & 1.188 & 0.766 & 1.842 \\
\hline $80 \geq$ & -0.3179 & 0.1739 & 0.728 & 0.460 & 1.151 \\
\hline \multicolumn{6}{|l|}{ Sex } \\
\hline Male & -0.2299 & 0.0170 & 0.795 & 0.658 & 0.960 \\
\hline \multicolumn{6}{|l|}{ Race } \\
\hline Black & 0.6134 & $<0.0001$ & 1.847 & 1.445 & 2.361 \\
\hline Asian & 0.6548 & $<0.0001$ & 1.925 & 1.395 & 2.655 \\
\hline Other/Unknown & 0.5333 & $<0.0001$ & 1.704 & 1.362 & 2.133 \\
\hline \multicolumn{6}{|l|}{ Payment method } \\
\hline Medicaid & -0.0458 & 0.7818 & 0.955 & 0.691 & 1.321 \\
\hline Medicare & -0.0107 & 0.9397 & 0.989 & 0.750 & 1.305 \\
\hline Self-pay & -0.3020 & 0.3972 & 0.739 & 0.367 & 1.488 \\
\hline \multicolumn{6}{|l|}{ Comorbidities } \\
\hline Heart failure & 0.1429 & 0.3397 & 1.154 & 0.860 & 1.547 \\
\hline $\begin{array}{l}\text { End stage renal } \\
\text { Disease }\end{array}$ & 0.6184 & 0.0017 & 1.856 & 1.262 & 2.729 \\
\hline COPD & -0.1216 & 0.3466 & 0.886 & 0.687 & 1.141 \\
\hline Hypertension & 0.1239 & 0.2142 & 1.132 & 0.931 & 1.376 \\
\hline Diabetes mellitus & 0.0833 & 0.3824 & 1.087 & 0.902 & 1.310 \\
\hline \multicolumn{6}{|l|}{ BMI } \\
\hline Unknown & -0.4645 & 0.0002 & 0.628 & 0.491 & 0.804 \\
\hline $30 \leq$ & -0.0545 & 0.6171 & 0.947 & 0.765 & 1.173 \\
\hline \multicolumn{6}{|l|}{ Admit source } \\
\hline Home & 0.9060 & $<0.0001$ & 2.474 & 1.850 & 3.310 \\
\hline Rehabilitation & 0.2904 & 0.2528 & 1.337 & 0.813 & 2.199 \\
\hline $\begin{array}{l}\text { Transfer from acute } \\
\text { care hospital }\end{array}$ & 0.0544 & 0.8017 & 1.056 & 0.691 & 1.614 \\
\hline \multicolumn{6}{|l|}{$\begin{array}{l}\text { Oxygen saturation on } \\
\text { presentation }\end{array}$} \\
\hline $80-89$ & 0.6871 & $<0.0001$ & 1.988 & 1.511 & 2.616 \\
\hline $90 \leq$ & 0.9232 & $<0.0001$ & 2.517 & 1.962 & 3.230 \\
\hline \multicolumn{6}{|l|}{ Proning } \\
\hline Yes & 1.1840 & $<0.0001$ & 3.267 & 2.667 & 4.003 \\
\hline
\end{tabular}

Abbreviations: BMI, body mass index; COPD, chronic obstructive pulmonary disease 
medRxiv preprint doi: https://doi.org/10.1101/2020.08.05.20168146; this version posted August 6, 2020. The copyright holder for this preprint (which was not certified by peer review) is the author/funder, who has granted medRxiv a license to display the preprint in perpetuity.

All rights reserved. No reuse allowed without permission. 